\title{
Quantitative proteomic analysis of differentially expressed proteins in tubers of potato plants differing in resistance to Dickeya solani
}

\author{
Renata Lebecka (1D) - Michal Kistowski • \\ Janusz Dẹbski • Katarzyna Szajko • Zofia Murawska • \\ Waldemar Marczewski
}

Received: 12 February 2019 / Accepted: 1 May 2019/Published online: 18 May 2019

(C) The Author(s) 2019

\begin{abstract}
Aims This study aims the detection of proteins associated with increased resistance of tubers to necrotrophic bacteria Dickeya solani in tetraploid and diploid potato plants.

Methods Comparative analysis of differently expressed proteins in tuber tissue of potato cultivars and diploid interspecific hybrids of Solanum, differing in resistance to Dickeya solani, was performed using nano-liquid chromatography coupled with tandem mass spectrometry (LC-MS-MS/MS). Two highly resistant (Bea and Humalda) and three susceptible (Irys, Katahdin, Ulster Supreme) potato cultivars, and the highly resistant (DG 00-270) and the susceptible (DG 08-305) diploid clones, were studied. Proteins were extracted from wounded potato tubers inoculated with bacteria at an early symptomatic phase of infection and from controls,
\end{abstract}

Responsible Editor: Matthew G. Bakker.

Electronic supplementary material The online version of this article (https://doi.org/10.1007/s11104-019-04125-7) contains supplementary material, which is available to authorized users.

R. Lebecka $(\bowtie) \cdot$ K. Szajko $\cdot$ Z. Murawska •

W. Marczewski $(\square)$

Plant Breeding and Acclimatization Institute, National Research Institute, Młochów Research Center, Platanowa 19,

05-831 Młochów, Poland

e-mail: r.lebecka@ihar.edu.pl

e-mail: w.marczewski@ihar.edu.pl

M. Kistowski · J. Dębski

Institute of Biochemistry and Biophysics, Mass Spectrometry

Laboratory, Polish Academy of Sciences, Pawińskiego 5A,

02-106 Warsaw, Poland i.e., intact tubers and wounded mock-inoculated tubers. Data are available via ProteomeXchange with identifier PXD013009.

Results Eight constitutive differentially expressed proteins with fold changes $\geq 1.9$ and $q$-value $\leq 0.1$ between the resistant and susceptible cultivar groups after D. solani infection were selected. Probable inactive patatin-03-Kuras 1 and the proteinase inhibitor PTI exhibited significantly increased protein abundances after bacterial inoculation in both resistant cultivars compared to the susceptible cultivars. In the diploid clones, only metallocarboxypeptidase and metallocarboxypeptidase-like inhibitors exhibited much higher fold changes following pathogenic invasion (274.4- and 368.6-fold, respectively) than after mock inoculation (165.5- and 130.7-fold, respectively). Conclusions These results show that different proteins indicating significant fold changes between the resistant and susceptible potato cultivars and diploid clones are induced at an early phase of symptomatic $D$. solani infection.

Keywords Potato tubers · Protein expression · Dickeya solani $\cdot$ Resistance $\cdot$ Soft rot
Abbreviations
CFU
CI1
DI
DS
LC-MS-MS/MS
colony forming units
chymotrypsin inhibitor
disease incidence
disease severity
liquid chromatography coupled
with tandem mass spectrometry 
MCPI

PCA

PI

PI2

PT

PT3K1

THI1 metallocarboxypeptidase inhibitor

Principal component analysis

proteinase inhibitor PTI

proteinase inhibitor type-2

patatin

probable inactive patatin-03-

Kuras 1

thiamine thiazole synthase

\section{Introduction}

Among the several soft rot enterobacterial necrotrophic pathogens of the two genera Pectobacterium and Dickeya, which cause blackleg in potato plants and soft rot of potato tubers, Dickeya solani has received the most attention due to highly aggressive infection caused by this pathogen in potato plants and the ability of this species to initiate disease occurrence at low inoculum levels (Czajkowski et al. 2009; Toth et al. 2011). Potato tubers can be infected by bacteria through wounds, natural openings (stomata, lenticels), or stolons. Seed tubers infected with bacteria are the main sources of inocula. Bacteria can move throughout the plant via the water-conducting tissues and can infect growing plants and progeny tubers through stolons. Infected seed tubers may also rot in the soil and reinfect growing potato plants (through roots) and progeny tubers (directly through wounds and lenticels or through stolons). Potato tubers can be contaminated with pectinolytic bacteria and infected through wounds during harvest, transport and grading. Elphinstone and Perombelon (1986) stated that a single rotting tuber contaminated $c$. $100 \mathrm{~kg}$ of potatoes during mechanical grading, c. 50\% being contaminated with $10^{4}-10^{5}$ bacteria per tuber. There is no chemical control that can be applied, and extreme resistance has not been observed in the genus Solanum. Mapping studies in a diploid population originating from hybrids of Solanum chacoense and Solanum yungasense have shown the complexity of the inheritance of resistance to Pectobacterium atrosepticum (Zimnoch-Guzowska et al. 2000). Broad studies on soft rot resistance have shown wide-ranging variations of partial resistance in potato cultivars and candidate breeding lines in France (Pasco et al. 2006). Tuber infection occurs in two phases: an asymptomatic phase, in which bacteria do not express genes encoding plant cell walldegrading enzymes (Toth and Birch 2005), and a late

phase, in which cell wall-degrading enzymes genes are activated by various means, such as quorum sensing, temperature, lack of nutrients and low oxygen conditions (Pérombelon 2002; Sepulchre et al. 2007; Davidsson et al. 2013). The products of pectinolytic enzymes activate plant defense (Sepulchre et al. 2007). In oxygen-rich conditions, a barrier-like mechanism of bacterial resistance is observed in tubers as a result of a rapid form of wound healing (Chung et al. 2017).

Proteomics is a powerful tool for the study of defense mechanisms associated with plant-pathogen interactions. Proteomics could be useful for determination of quantitative and qualitative changes in proteins involved in the defense response in plants and to understand the relationships between these proteins and biological resistance (Fang et al. 2015). Potato tuber extract increased the expression more than 40 proteins in the secretome of the soft rot enterobacterium $P$. atrosepticum, including known virulence factors, such as pectic enzymes and proteases (Mattinen et al. 2007). The first proteomic study of potato tissue compared the protein expression profiles of $P$. atrosepticumand mock-inoculated tubers of two potato cultivars (Barzic and Com 2012). Thirteen proteins were upregulated $48 \mathrm{~h}$ post inoculation in the partially resistant potato cultivar Kerpondy, but not in the susceptible cultivar Bintje, in comparison to the mock-inoculated tubers.

In our study we report, for the first time, the detection of proteins associated with increased resistance of tubers to D. solani in tetraploid and diploid potato plants. Nano-LC-MS-MS/MS (nano-liquid chromatography coupled with tandem mass spectrometry) was used to identify differentially expressed proteins between the resistant and susceptible potato plants following D. solani invasion at an early symptomatic phase of infection. In addition, differentially expressed proteins between the resistant and susceptible potato plants in intact tubers and after mock inoculation are presented.

\section{Materials and methods}

\section{Plant material}

Four potato cultivars-Katahdin and three Katahdinderived cultivars, namely, Bea, Humalda, and Ulster Supreme-were obtained from the potato collection at the Plant Breeding and Acclimatization Institute, 
National Research Institute, Bonin, Poland. The cultivar Irys, used as standard of high susceptibility of tubers to pectinolytic bacteria, scored 2 on a scale of 1 to 9 , where 9 is the most resistant, according to the descriptions of potato cultivars registered in Poland. Two diploid clones, namely, the highly resistant DG 00-270 and the susceptible DG 08-305, were obtained from the Młochów collection of diploid potato plants. DG 00270 was derived by intercrossing Solanum tuberosum L with Solanum phureja Juz. and Bukasov and other wild species: S. chacoense Bitter, S. yungasense Hawk, Solanum verrucosum Schltdl, and Solanum microdontum Bitter. In addition, the moderately resistant cultivar Glada, which scored 5 on a scale of 1 to 9 , where 9 is the most resistant, was used to test the kinetics of symptom development under the applied experimental conditions.

Bacterial inoculum

The bacterial strain of D. solani, IFB0099 syn. IPO2276 (IPO: the collection of Plant Research International, Wageningen, The Netherlands), was used in this study. This strain was kindly provided by Prof. E. Lojkowska, from the collection of the Intercollegiate Faculty of Biotechnology University of Gdańsk and Medical University of Gdańsk, Poland. The bacterium (stored at $-70^{\circ} \mathrm{C}$ ) was first grown on LB agar medium for $24 \mathrm{~h}$ at $27^{\circ} \mathrm{C}$ and then resuspended in sterile deionized water, and the suspension was adjusted to an optical density $\left(\mathrm{OD}_{600}\right)$ of 1.0 , equivalent to $10^{9} \mathrm{CFU} \mathrm{ml}{ }^{-1}$, using a spectrophotometer (Hitachi U-1900, Tokyo, Japan).

Testing of potato cultivars/clones for tuber soft rot resistance

Tuber resistance to pectinolytic bacteria was tested by the method described by Lebecka et al. (2018). Tubers were stored in the dark at $8{ }^{\circ} \mathrm{C}$ for 3 months before the experiments were conducted. Each tuber surfacedisinfected in $1 \%$ sodium hypochlorite solution for $15 \mathrm{~min}$, rinsed in distilled water and air dried at room temperature 1 day before inoculation, was wounded with a steel rod $(10 \mathrm{~mm}, \varnothing 2 \mathrm{~mm})$ and inoculated with $10 \mu \mathrm{L}$ of bacterial suspension, which was pipetted into a wound hole. The holes were sealed with Vaseline and a piece of a parafilm. The tubers were externally sprayed with water, enclosed in boxes and kept for 3 days at $26^{\circ} \mathrm{C}$. Six experiments were conducted in January of
3 years (2015-2017). In total, during the 3 years of testing, 58 tubers were tested for each potato cultivar, and 40 tubers were tested for diploid clones. The resistance of potato tubers can be expressed as the number of successfull infected tubers and the level of infection in infected tubers. Therefore two components of resistance were assessed: disease severity (DS), expressed as mass of macerated tissue from tubers with symptoms of infection, and disease incidence (DI), expressed as the average percentage of tubers with symptoms of rot. Statistical analyses were performed using Statistica 10 software (Statsoft Inc. 2011). To test the effect of the potato cultivar/clone, the year and interactions with DS values, two-way factorial ANOVA was used. To test the significance of differences among cultivars, Tukey's test was used.

Determining the time of symptoms occurrence in wounded potato tubers inoculated with bacteria

To identify the early phase of symptom development following the inoculation of potato tubers with the bacterium D. solani IFB0099 for the applied experimental conditions, the kinetics of symptom development were analyzed. At one-hour intervals starting $5 \mathrm{~h}$ after inoculation, the rotten tissue was weighed for 6 tubers from each of the two potato cultivars, namely, Irys and Glada.

Inoculation of potato tubers for protein extraction

Tubers were stored in the dark at $8{ }^{\circ} \mathrm{C}$ for 6 months before the experiments were conducted. For proteomic analyses, tubers were inoculated as described above. Control tubers were kept intact or wounded and treated with sterilized water instead of the bacterial suspension. Two samples from each of two different tubers on each of two different experimental dates were collected $8 \mathrm{~h}$ post inoculation. In total, 8 samples for each of five potato cultivars for every three combinations (of bacteria-inoculated, mock-inoculated and intact tubers) were examined. Accordingly, 8 samples for each of two diploid clones for every two combinations, bacteriainoculated and mock-inoculated tubers and 4 samples for intact-tubers, were examined.

\section{Protein extraction}

The total proteomes of the tuber tissues were extracted as described by Murawska et al. (2017). Tuber tissue 
fragments of up to $250 \mathrm{mg}$ were cut out from the edges of inoculated or symptom-exhibiting tubers using a corkborer (Ø $4 \mathrm{~mm})$. The samples were immediately frozen in liquid nitrogen and then kept in a freezer at $-80{ }^{\circ} \mathrm{C}$ before freeze-drying for 2 days. Lyophilized samples were homogenized using micropestles, and proteins were solubilized in $135 \mu \mathrm{l}$ of $25 \mathrm{mM}$ ammonium bicarbonate and $15 \mu \mathrm{l}$ of $4 \%$ SDS. After $15 \mathrm{~min}$ of sonication, $100 \mu \mathrm{l}$ of $25 \mathrm{mM}$ ammonium bicarbonate was added, and the samples were vortexed and then centrifuged for $10 \mathrm{~min}$ at $12000 \times \mathrm{g}$. The supernatant was collected, and the total protein content in the sample was measured using the bicinchoninic acid assay (Smith et al. 1985). The protein concentration was estimated twice: once after protein extraction from homogenized tissue, to minimize variations resulting from material isolation and tissue homogenization, and once after acetone precipitation, to minimize the effect of the resolubilization of different proteins among samples. For digestion of peptide bonds carboxyterminal to lysine under high urea concentrations, the total protein content (and hence the amount of enzyme) in the samples was adjusted to $50 \mu \mathrm{g}$ with $20 \mu \mathrm{l}$ of $100 \mathrm{mM}$ ammonium bicarbonate containing $0.1 \mu \mathrm{g}$ of endoproteinase Lys-C (Pierce ${ }^{\mathrm{TM}}$ Lys-C Protease, MSgrade, 90,307). After $90 \mathrm{~min}$ of incubation at room temperature, to disrupt disulfide bonds, $1 \mu \mathrm{l}$ of $0.5 \mathrm{M}$ Tris (2-carboxyethyl)phosphine hydrochloride was added, and the samples were incubated for $20 \mathrm{~min}$ at $60{ }^{\circ} \mathrm{C}$. To prevent the regeneration of disulfide bridges, $3 \mu \mathrm{l}$ of 0.2 MS-methyl methanethiosulfonate was added. Overnight tryptic hydrolysis of $50 \mu \mathrm{g}$ of total protein in the samples was performed at $37{ }^{\circ} \mathrm{C}$ using $20 \mu \mathrm{l}$ of sequencing-grade modified trypsin (Promega, V5117). Two microliters of 1\% TFA (trifluoroacetic acid) was added to the samples, which were then stored in refrigerator until nano-LC-MS-MS/MS analysis.

\section{Mass spectrometry}

Peptide mixtures were analyzed by nano-LC-MS-MS/ MS using a nanoACQUITY (Waters) LC system and a Q-Exactive mass spectrometer (Thermo Electron Corp., San Jose, CA). The peptide mixture was applied to an RP-18 precolumn (nanoACQUITY Symmetry® C18, Waters $186,003,514$ ) using water containing $0.1 \%$ TFA as a mobile phase and then transferred to a nano-HPLC RP-18 column (nanoACQUITY BEH C18, Waters $186,003,545)$ using an acetonitrile gradient (5-35\%
$\mathrm{AcN}$ in $180 \mathrm{~min}$ ) in the presence of $0.05 \%$ formic acid with a flow rate of $250 \mathrm{nl} / \mathrm{min}$. The column outlet was directly coupled to the electrospray ion source of the spectrometer functioning under a data-dependent MSto-MS/MS switch. A blank run ensuring lack of cross contamination from previous samples preceded each analysis.

The raw data acquired were processed by Mascot Distiller followed by a Mascot Search (Matrix Science, London, UK, on-site license) against the UniProt Solanum tuberosum database (June 2015 release) restricted to human sequences. The search parameters were as follows: precursor and product ion mass tolerance of $30 \mathrm{ppm}$ and $0.1 \mathrm{Da}$, respectively; enzyme specificity, trypsin; missed cleavages allowed, 1; fixed modification of cysteine by a methylthio group; and variable modification by methionine oxidation. Peptides with Mascot scores exceeding the threshold value corresponding to $<5 \%$ of the expected value, as calculated by Mascot, were considered to be positively identified.

The mass spectrometry data have been deposited to the ProteomeXchange Consortium via the PRIDE [1] partner repository with the dataset identifier PXD013009 and https://doi.org/10.6019/PXD013009.

Quantitative analysis was performed as described by Bakun et al. (2012). Briefly, the mass calibration and data filtering described above were carried out with MScan software, which was developed in-house (http://proteom.ibb.waw.pl/). Only proteins represented by at least two peptides were considered, and proteins identified by a subset of peptides from another protein were excluded. Peptides lists from the LC-MS/MS runs that matched the acceptance criteria were merged and overlaid onto 2-D heat maps generated from the LC$\mathrm{MS} / \mathrm{MS}$ datasets using $\mathrm{m} / \mathrm{z}$ and retention time coordinates and validated by predicted and observed isotopic pattern correlation (acceptance criteria: $\mathrm{RMS}>90 \%$ ) using MSparky (http://proteom.ibb.waw.pl/). Peptide intensities were determined as the surfaces of the tagged isotopic envelopes. Finally, lists of identified peptides with corresponding quantitative values were exported for statistical analysis, which was carried out with the Diffprot software program (version 1.5.19; 3.01.2013) developed in-house (Malinowska et al. 2012). Prior to analysis, quantitative values were normalized with LOWESS. Proteins with more than $90 \%$ common peptides were clustered, and only peptides unique to the cluster were used for statistical analysis. 
Only proteins with $q$-values $\leq 0.1$ were taken into consideration during further analysis.

Principal component analysis was performed for proteins analysed from tubers of the five potato cultivars $8 \mathrm{~h}$ post mock- and bacteria-inoculation. The features used for PCA were normalized and log-transformed peptide intensitie, with median value imputation of missing data. Peptides missing in more than $30 \%$ of samples were removed from the data set. The analysis itself was performed using Scikit-learn 0.19.2 (Pedregosa et al. 2011) and the results visualized with ggplot 2 (Wickham 2017).

\section{Results}

Soft rot resistance of tubers of potato cultivars and diploid hybrids of Solanum spp.

Resistance to tuber soft rot was evaluated under laboratory conditions using point inoculation of whole tubers. The DS data used for analysis included only data for tubers with symptoms of infection. Two-way ANOVA indicated the significant effects of potato cultivar/clone $(P<0.001)$ and year of testing $(P=0.0034)$, but not of the interaction of cultivar and year $(P=0.072)$, on DS values. The ratings for the responses of potato cultivars and diploid clones to soft rot bacteria are shown in
Figs. 1 and 2. Post hoc analysis of the DS data has shown that two potato cultivars, namely, Humalda and Bea, and one diploid clone, namely, DG 00-270, were significantly more resistant than the three potato cultivars Katahdin, Ulster Supreme, and Irys and the diploid clone DG 08-305. For DI, the percentage of tubers with symptoms of rot ranged from 63 to $84 \%$ in a group of resistant cultivars/clones and from 95 to $100 \%$ in a group of susceptible cultivars/clones. The correlation coefficient between DS and DI for tested cultivars/ clones was $r=0.729$ with $P=0.06$.

Determining the time of symptoms occurrence in wounded potato tubers inoculated with bacteria

Symptoms of rot in tubers inoculated with $D$. solani under the conditions applied for evaluation of tuber resistance to soft rot at one-hour intervals were not observed $7 \mathrm{~h}$ post inoculation. However, the symptoms were visible $8 \mathrm{~h}$ after inoculation, regardless of the level of resistance to bacteria in the two tested potato cultivars (Fig. S1).

Proteins associated with $D$. solani resistance

Eight total samples from four different tubers from each of the cultivars were tested. Increase in protein abundance in the resistant cultivars (16 samples) compared to

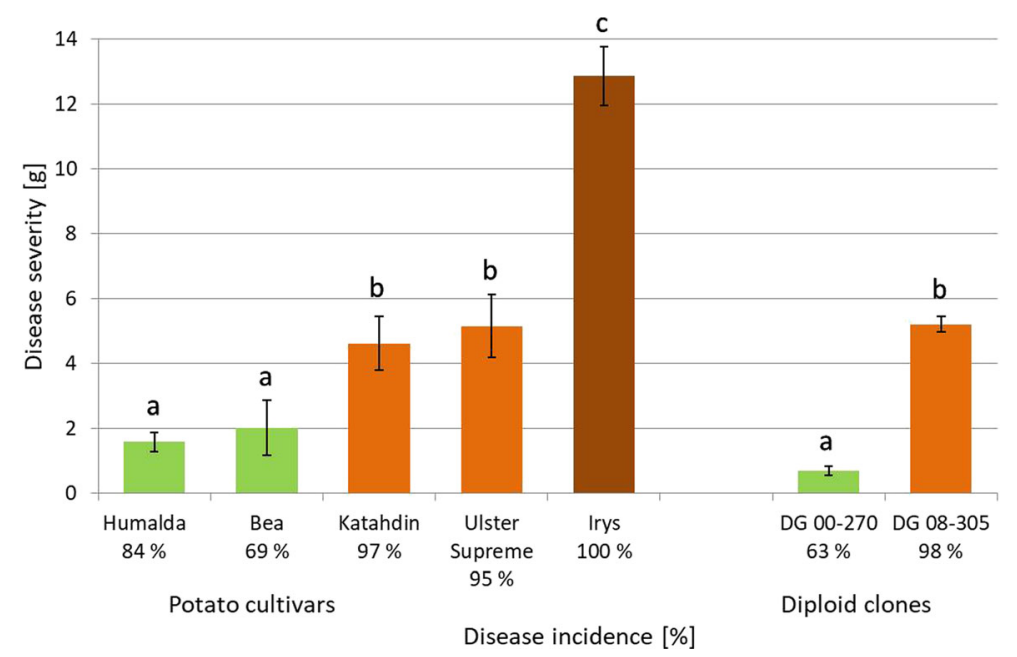

Fig. 1 Disease severity (DS) and disease incidence (DI) of potato cultivars/diploid clones after inoculation of tubers with $D$. solani. DS is expressed as weight of rotten tissue [g], and DI is expressed as percentage $(\%)$ of tubers with symptoms of rot. Each value represents the mean number of successfully infected tubers out of
58 tubers for the cultivars and 40 tubers for the clones after incubation at $26{ }^{\circ} \mathrm{C}$ for 3 days. The tubers were assayed in six independent experiments over 3 years. Means followed by the same letter do not differ significantly according to Tukey's range test $(P<0.05)$. Error bars indicate the standard error 


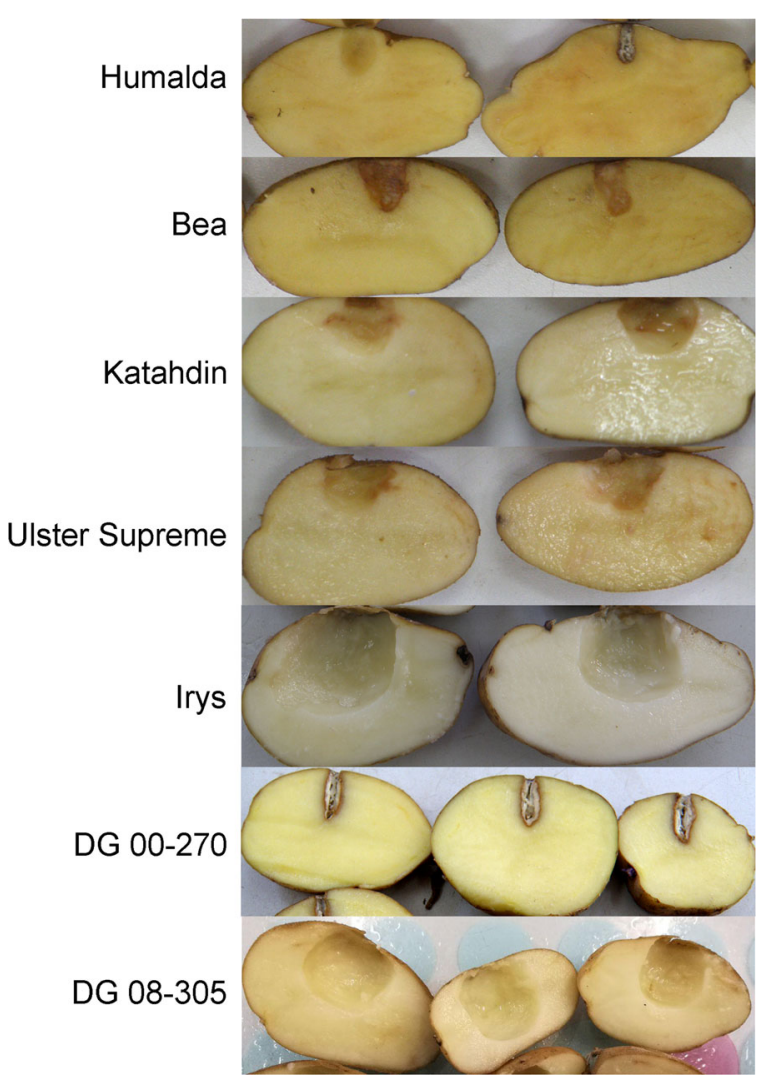

Fig. 2 Reaction of potato cultivars and diploid clones to inoculation of tubers with bacteria with $D$. solani and incubation at temperature $26{ }^{\circ} \mathrm{C}$ for 3 days. High resistance is expressed in the form of wound healing (the second tuber of cultivar Humalda and tubers of the diploid clone DG 00-270) and was used for calculation the disease incidence. The level of infection (disease severity) in infected tubers was expressed as weight of rotten tissue [g], which was removed from cut tubers

the susceptible group (24 samples) were analyzed for each of three treatments. For each of the highly resistant (DG 00-270) and the susceptible (DG 08-305) diploid clones, from four to eight samples for each of three treatments were compared. On average, in a single experiment, after filtering out proteins with low Mascot scores or those identified by one peptide only, approximately 1450 (ranging from 1233 to 1733) proteins were selected for quantification. From this data, differentially expressed proteins with ratios $\geq 1.9$ and q-values $\leq 0.1$ between the resistant and susceptible samples were selected. There were 8 constitutively expressed proteins that exhibited significant fold changes between the cultivar groups following bacterial infection: six exhibited increased abundance - probable inactive patatin-03Kuras 1 (PT3K1), proteinase inhibitor PTI (PI), proteinase inhibitor type 2 (PI2), chloroplastic thiamine thiazole synthase (THI1), 4 subunits of chymotrypsin inhibitor (CI1), 4 isoforms of patatin (PT) and two exhibited decreased abundance -4 other isoforms of patatin and defensing-like protein. For PI2, PT3K1, CI1 and PT, significant changes were observed after mock inoculation. PT also exhibited differential abundance in intact tubers. The fold change values are shown in Table 1. When the proteins of each of the resistant cultivars were compared with those of the susceptible group individually, PT3K1 and PI exhibited significantly increased protein abundance after $D$. solani inoculation in both resistant cultivars (Fig. 3). PI2, THI1, CI1 and PT exhibited increased abundance in D. solani-infected Humalda tubers and not in the Bea cultivar (Table 2).

Principal component analysis of data obtained from potato tubers of the five cultivars, both bacteria- and mock-inoculated, showed that potato cultivars were not well separated from each other in the dimension of the first component (Fig. 4). However, the cultivars were well separated in the dimension of the second component. PC1 explained $11 \%$ and $\mathrm{PC} 2-8 \%$ of total variance.

In the diploid clones, 21 proteins with significant fold changes were identified between DG 00-270 and DG 08-305 after D. solani infection. However, only metallocarboxypeptidase inhibitor (MCPI) and MCPIlike proteins exhibited much higher fold changes following pathogenic invasion (274.4- and 368.6-fold, respectively) than after mock inoculation (165.5- and 130.7-fold, respectively) and in intact tubers (nonsignificant and 49.2-fold, respectively) (Table 3).

\section{Discussion}

For the proteomics studies, five potato cultivars and two diploid clones of Solanum were selected based on the results of six biological tests, conducted in three consecutive years, in which DI and DS were evaluated in wounded tubers inoculated with the bacterium D. solani. An aggressive strain of D. solani IFB0099 in studies of Golanowska et al. (2015) has been selected for inoculation of potato in tuber soft rot assays and in protein extraction experiments. The wound inoculation method for testing tuber resistance to pectinolytic bacteria gives similar results as immersion of mechanically harvested tubers in a bacterial inoculum (Tzeng et al. 1990). Two potato cultivars, namely, Humalda and Bea, and one diploid clone, namely, DG 00-270, exhibited 
Table 1 List of proteins in the resistant group that significantly differed from those in the susceptible group

\begin{tabular}{|c|c|c|c|c|c|c|c|c|c|c|}
\hline \multirow{2}{*}{$\begin{array}{l}\text { Protein } \\
\text { Accession }^{\mathrm{a}}\end{array}$} & \multirow{2}{*}{$\begin{array}{l}\text { Description } \\
\text { Protein }\end{array}$} & \multicolumn{3}{|c|}{ Control not wounded } & \multicolumn{3}{|c|}{ Wounded + D. solani } & \multicolumn{3}{|c|}{ Wounded + Water } \\
\hline & & $\begin{array}{l}\text { Fold } \\
\text { change }^{b}\end{array}$ & $q^{\mathrm{c}}$ & $\#^{\mathrm{d}}$ & $\begin{array}{l}\text { Fold } \\
\text { change }\end{array}$ & $q$ & \# & $\begin{array}{l}\text { Fold } \\
\text { change }\end{array}$ & $q$ & \# \\
\hline $\begin{array}{l}\text { M0ZPU4 } \\
\text { M0ZPU7 } \\
\text { M0ZZR6 } \\
\text { M1B8F8 } \\
\text { Q00782 }\end{array}$ & Proteinase inhibitor type- 2 & 12.40 & 1.0000 & 21 & 106.70 & 0.0003 & 46 & 66.93 & 0.0198 & 44 \\
\hline Q3YJS9 & Probable inactive patatin-03-Kuras 1 & 6.97 & 1.0000 & 150 & 7.63 & 0.0003 & 198 & 4.37 & 0.0014 & 192 \\
\hline M1BNZ3 & Thiamine thiazole synthase, chloroplastic & 1.58 & 1.0000 & 14 & 4.60 & 0.0065 & 14 & 2.28 & 0.241 & 12 \\
\hline P01079 & Proteinase inhibitor PTI & 1.43 & 1.0000 & 10 & 4.07 & 0.0003 & 22 & 2.72 & 0.6090 & 21 \\
\hline P01052 & $\begin{array}{l}\text { Chymotrypsin inhibitor I, A, B and C } \\
\text { subunits }\end{array}$ & 5.61 & 1.0000 & 12 & 12.41 & 0.0100 & 12 & 13.93 & 0.0137 & 12 \\
\hline $\begin{array}{l}\text { Q3YJT5 } \\
\text { Q2MY48 }\end{array}$ & $\begin{array}{l}\text { Patatin-05 } \\
\text { Patatin-03 }\end{array}$ & 2.09 & 0.0167 & 121 & 1.89 & 0.0003 & 160 & 2.14 & 0.0035 & 165 \\
\hline Q2MY44 & Patatin-07 & & & & & & & & & \\
\hline M1BFJ0 & Uncharacterized & & & & & & & & & \\
\hline M1AGX5 & Patatin & & & & & & & & & \\
\hline Q2MY38 & Patatin-13 & & & & & & & & & \\
\hline $\begin{array}{l}\text { Q41487 } \\
\text { Q3YJT4 }\end{array}$ & $\begin{array}{l}\text { Patatin-16 } \\
\text { Patatin-1-Kuras } 2\end{array}$ & 0.34 & 1.0000 & 64 & 0.09 & 0.0036 & 119 & 0.21 & 0.4525 & 120 \\
\hline $\begin{array}{l}\text { Q2MY59 } \\
\text { Q2MY50 } \\
\text { Q2MY60 } \\
\text { Q2MY58 }\end{array}$ & $\begin{array}{l}\text { Patatin group A-2 } \\
\text { Patatin-01 }\end{array}$ & & & & & & & & & \\
\hline $\begin{array}{l}\text { K7WJX9 } \\
\text { M1B7U1 } \\
\text { P20346 }\end{array}$ & Defensin-like protein & 1.12 & 1.0000 & 4 & 0.26 & 0.0372 & 10 & 0.27 & 0.2552 & 11 \\
\hline
\end{tabular}

${ }^{\mathrm{a}}$ UniProt identifier; ${ }^{\mathrm{b}}$ increase in protein abundance in the resistant group (Bea and Humalda cultivars) compared to the susceptible group (Katahdin, Ulster Supreme and Irys cultivars); significant changes in bold; ${ }^{\mathrm{c}} q$-value as reported by Diffprot; ${ }^{\mathrm{d}}$ number of peptides used in the comparison

significantly more resistance to tuber maceration than the three potato cultivars, namely, Katahdin, Ulster Supreme, and Irys, and the diploid clone DG 08-305 used in this study. The clone DG 00-270 exhibited the lowest DS (0.7 g) and DI (63\%); however, the DS of this clone did not differ significantly from those of the two resistant potato cultivars (1.6 and $2.0 \mathrm{~g}$ ) but differed considerably from that of the most susceptible cultivar, Irys (12.9 g).

Pectinolytic bacteria are characterized by high levels of parasitism. These bacteria can coexist with their host plants without causing damage. The duration of latent infection is dependent on many factors. We determined the time of symptom occurrence under our experimental conditions, and accordingly, the tuber tissue samples used for proteomic studies were collected $8 \mathrm{~h}$ post inoculation, which reflects an early symptomatic phase of infection. In this phase, bacteria produce an arsenal of plant cell wall-degrading enzymes and trigger the resistance response in potato plants (Sepulchre et al. 2007). Simultaneously, synthesis of lignin and the prosuberin lamella in potato tubers occur $4 \mathrm{~h}$ post wounding (Lapierre et al. 1996).

Comparison of the protein expression profiles of pathogen-inoculated plants and controls provides information on only the response of plants to pathogenic attack, not on the mechanisms by which plants resist pathogenic infection (Zhang et al. 2013). In our study, to identify proteins associated with resistance processes, the protein profiles of tubers from potato cultivars or 
Fig. 3 Box plots of relative abundance of proteins in the tested cultivars: a the proteinase inhibitor PTI, b the probable inactive patatin-3-Kuras 1 . The box represents quartiles, and the band inside the box is the median. The whiskers extend to data extremes. No outlier values more than 1.5 times the interquartile range from the box were observed a

P01079: Proteinase inhibitor PTI (bacteria, 8h)

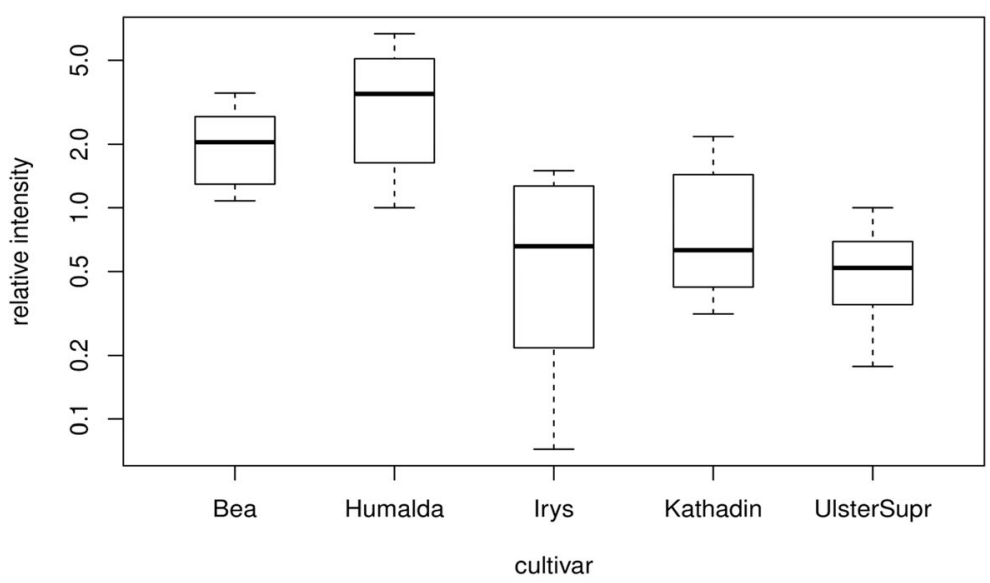

b

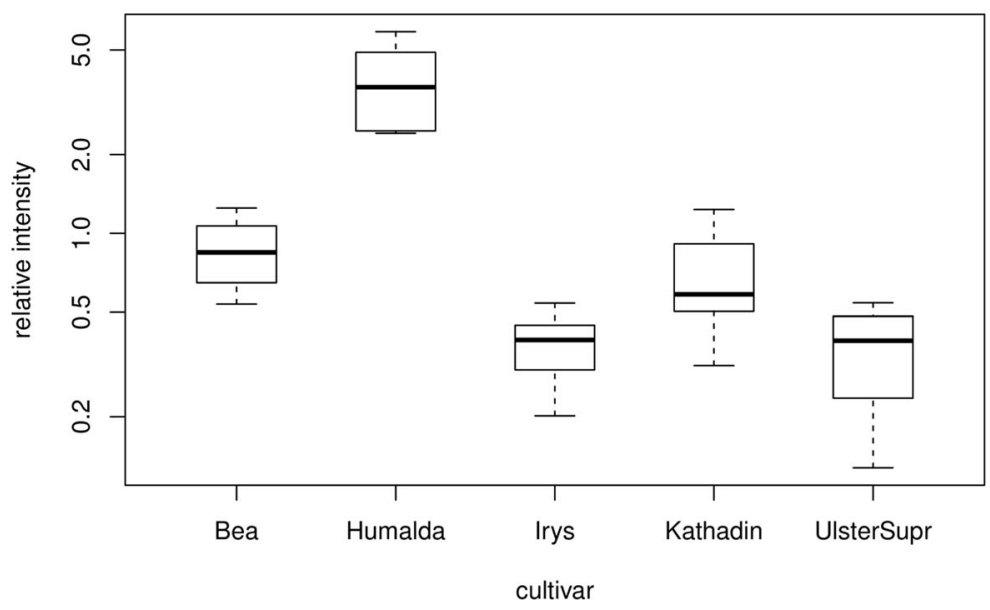

diploid clones that differed in D. solani resistance were analyzed. The cultivated potato is a highly heterozygous species with complex genetics. To minimize the possibility of false positive selection of proteins underlying plant resistance to the pathogen, we used samples from two groups of potato cultivars that differed in $D$. solani resistance. Six proteins, namely, PI2, PT3K1, THI1, PTI, CI1 and PT, were upregulated in tubers from the resistant group compared to the susceptible group after D. solani inoculation (Table 1). Four of these proteins, namely, PI2, THI1, CI1 and PT, exhibited significantly higher fold change values in only the resistant cultivar Humalda and not in the resistant cultivar Bea (Table 2). This result confirms the complexity of the defensive response in potato tubers against bacterial invasion.

Two proteins, namely, PT3K1 and PI, were revealed to be upregulated in both resistant cultivars (Fig. 3).
PT3K1 levels were increased to 2.3- and 20.9-fold in the tubers of the Bea and Humalda cultivars, respectively, upon inoculation with $D$. solani. The corresponding fold change values for PI were 3.2 and 4.4. In potato tubers, patatin isoforms play dual roles as storage proteins and as acyl hydrolases and esterases, indicating the contribution of this protein to the resistance to pests, pathogens and abiotic stress (Shewry 2003; Barta and Bartova 2008). Proteases, also called peptidases or proteinases, are enzymes that are responsible for peptide bond hydrolysis. These enzymes play roles in the regulation of many different processes in plant physiology and development, including an important role in pathogenesis (Van der Hoorn 2008). In potato tubers, bacterial pathogens degrade host tissue by producing cell walldegrading enzymes, such as pectin and pectate lyases, polygalacturonases, cellulases, and proteases 
Table 2 List of proteins that exhibited significant differences in expression between the resistant cultivars Bea or Humalda and the susceptible group

\begin{tabular}{|c|c|c|c|c|c|c|c|c|}
\hline \multirow{2}{*}{$\begin{array}{l}\text { Protein } \\
\text { Accession }^{\mathrm{a}}\end{array}$} & \multirow{2}{*}{$\begin{array}{l}\text { Description } \\
\text { Protein }\end{array}$} & \multirow[b]{2}{*}{ Cultivar } & \multicolumn{3}{|c|}{ Wounded $+D$. solani } & \multicolumn{3}{|c|}{ Wounded + Water } \\
\hline & & & Fold change ${ }^{\mathrm{b}}$ & $q^{\mathrm{c}}$ & $\#^{\mathrm{d}}$ & Fold change & $q$ & \# \\
\hline \multirow[t]{2}{*}{ Q00782 } & \multirow[t]{2}{*}{ Proteinase inhibitor type- 2} & Bea & 3.31 & 0.8529 & 18 & 3.32 & 0.8013 & 19 \\
\hline & & Humalda & 284.83 & 0.0003 & 46 & 173.88 & 0.0002 & 42 \\
\hline \multirow[t]{2}{*}{ Q3YJS9 } & \multirow[t]{2}{*}{ Probable inactive patatin-03-Kuras 1} & Bea & 2.25 & 0.0003 & 192 & 1.75 & 0.0710 & 171 \\
\hline & & Humalda & 20.85 & 0.0003 & 198 & 12.43 & 0.0002 & 190 \\
\hline \multirow[t]{2}{*}{ M1BNZ3 } & \multirow[t]{2}{*}{ Thiamine thiazole synthase, chloroplastic } & Bea & 3.30 & 0.8412 & 14 & 2.28 & 0.241 & 12 \\
\hline & & Humalda & 9.73 & 0.0122 & 14 & 2.90 & 0.4772 & 12 \\
\hline \multirow[t]{2}{*}{ P01079 } & \multirow[t]{2}{*}{ Proteinase inhibitor PTI } & Bea & 3.16 & 0.0280 & 22 & 2.89 & 0.0729 & 21 \\
\hline & & Humalda & 4.35 & 0.0126 & 22 & 3.41 & 0.2218 & 21 \\
\hline \multirow[t]{2}{*}{ P01052 } & \multirow[t]{2}{*}{ Chymotrypsin inhibitor I, A, B and C subunits } & Bea & 17.29 & 0.8468 & 8 & 1.10 & 0.7517 & 9 \\
\hline & & Humalda & 19.47 & 0.0666 & 12 & 39.31 & 0.2370 & 12 \\
\hline Q3YJT5 & Patatin-05 & Bea & 0.82 & 1.0000 & 73 & 1.95 & 0.0132 & 153 \\
\hline $\begin{array}{l}\text { Q2MY48 } \\
\text { Q2MY44 }\end{array}$ & $\begin{array}{l}\text { Patatin-03 } \\
\text { Patatin }\end{array}$ & Humalda & 3.16 & 0.0084 & 77 & 3.16 & 0.0008 & 77 \\
\hline M1AGX5 & Patatin-07 & & & & & & & \\
\hline
\end{tabular}

${ }^{a}$ UniProt identifier; ${ }^{b}$ increase in protein abundance in the resistant cultivars compared to the susceptible group (Katahdin, Ulster Supreme and Irys cultivars), significant changes in bold; ${ }^{\mathrm{c}} q$-value as reported by Diffprot; ${ }^{\mathrm{d}}$ number of peptides used in the comparison

(Pérombelon 2002; Toth et al. 2003). The strain D. solani IFB0099 (IPO 2276) used in our study is most closely related to the strain IPO 2222, which is most closely related to Dickeya dadantii 3947 (Van der Wolf et al. 2014; Pritchard et al. 2013), which produces a range of plant cell wall-degrading enzymes (Py et al. 1991; Kazemi-Pour et al. 2004). Protease activity is regulated by protease inhibitors (PIs). PIs are among the important defense related proteins and are divided into four classes: serine protease, metalloprotease, cysteine protease, and aspartic protease inhibitors (Van der Hoorn 2008; Rehman et al. 2017). PIs are associated with resistance and can inhibit proteinases of various plant pathogens (Ryan 1990). Mature potato tubers are rich sources of several PI families (Fischer et al. 2015). Valueva et al. (1998) have shown that infection of potato
Fig. 4 Principal component analysis investigates whether the quantified protein patterns cluster according to cultivar and inoculation treatment. The variation explained by $\mathrm{PC} 1$ is $12 \%$ and by PC2-8\%. Each point corresponds to the protein pattern of each replicate sample, projected onto a two-dimensional principal component space. The analysis shows separation of resistant and susceptible potato cultivars along the second component axis (PC2) indicating differences in protein abundance patterns

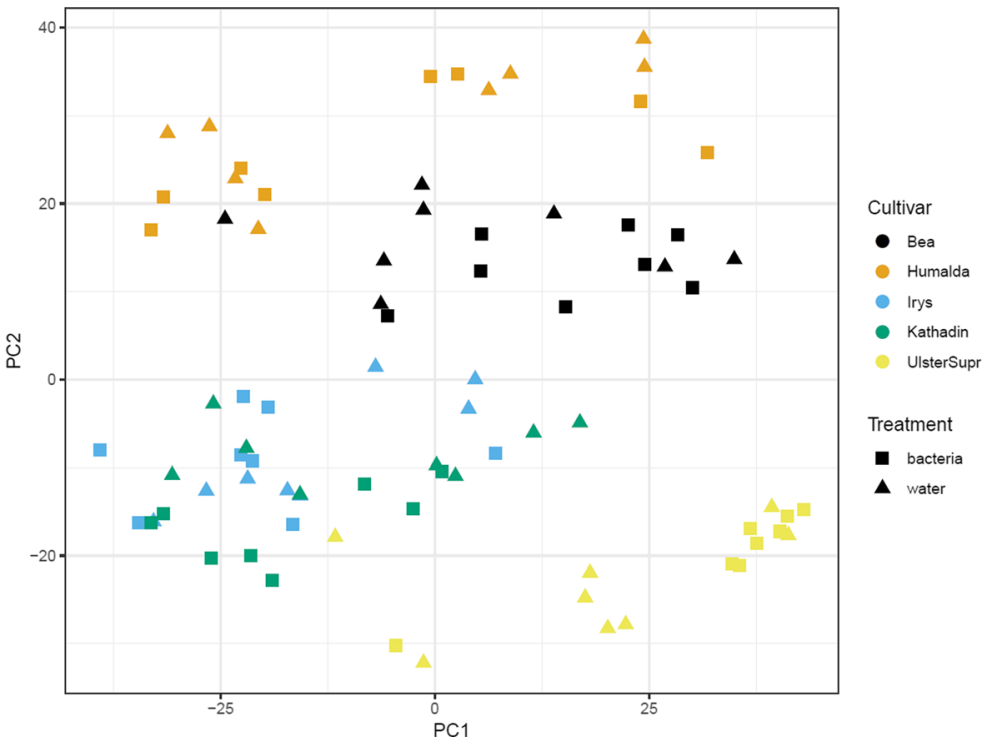


Table 3 List of proteins that exhibited significant differences in expression between the resistant diploid clone DG 00-270 and the susceptible DG 08-305

\begin{tabular}{|c|c|c|c|c|c|c|c|c|c|c|}
\hline \multirow{2}{*}{$\begin{array}{l}\text { Protein } \\
\text { Accession }^{\mathrm{a}}\end{array}$} & \multirow{2}{*}{$\begin{array}{l}\text { Description } \\
\text { Protein }\end{array}$} & \multicolumn{3}{|c|}{ Control not wounded } & \multicolumn{3}{|c|}{ Wounded $+D$. solani } & \multicolumn{3}{|c|}{ Wounded + Water } \\
\hline & & $\begin{array}{l}\text { Fold } \\
\text { change }^{b}\end{array}$ & $q^{\mathrm{c}}$ & $\#^{\mathrm{d}}$ & $\begin{array}{l}\text { Fold } \\
\text { change }\end{array}$ & $q$ & $\#$ & $\begin{array}{l}\text { Fold } \\
\text { change }\end{array}$ & $q$ & $\#$ \\
\hline M1D4V9 & metallocarboxypeptidase inhibitor & 1.06 & 1.0000 & 9 & 274.40 & 0.0001 & 22 & 165.48 & 0.0093 & 22 \\
\hline $\begin{array}{l}\text { M0ZJ50 } \\
\text { M1A6J6 }\end{array}$ & Putative metallocarboxypeptidase inhibitor-like & 49.15 & 0.0077 & 7 & 368.62 & 0.1114 & 16 & 130.70 & 0.1237 & 16 \\
\hline \multicolumn{11}{|l|}{ M1A6J5 } \\
\hline Q3YJS9 & Probable inactive patatin-03-Kuras 1 & 2.47 & 0.0002 & 130 & 3.00 & 0.0001 & 119 & 4.27 & 0.0009 & 116 \\
\hline $\begin{array}{l}\text { Q43652 } \\
\text { Q41435 }\end{array}$ & $\begin{array}{l}\text { Proteinase inhibitor type- } 2 \mathrm{CM} 7 \\
\text { Proteinase inhibitor type- } 2 \mathrm{~T}\end{array}$ & 1.06 & 1.0000 & 22 & 15.32 & 0.0001 & 22 & 17.75 & 0.0002 & 25 \\
\hline P84813 & Potamin-1 & & & & & & & & & \\
\hline P01080 & Proteinase inhibitor type- $2 \mathrm{~K}$ & & & & & & & & & \\
\hline J7EQ13 & Proteinase inhibitor type- 2 & & & & & & & & & \\
\hline M1B8F7 & Uncharacterized protein & & & & & & & & & \\
\hline M0ZMA9 & Similar to: pathogenesis related protein STH-2 & 0.9 & 1.0000 & 81 & 1.96 & 0.0001 & 57 & 1.59 & 0.0834 & 73 \\
\hline $\begin{array}{l}\text { B3F8F4 } \\
\text { M0ZI72 }\end{array}$ & Glutaredoxin & 1.56 & 0.8305 & 24 & 2.27 & 0.0056 & 19 & 3.86 & 0.0100 & 20 \\
\hline P08454 & Wound-induced proteinase inhibitor & 0.83 & 1.0000 & 76 & 13.26 & 0.0247 & 72 & 29.76 & 0.0002 & 74 \\
\hline $\begin{array}{l}\text { M1BMR6 } \\
\text { M1BMR7 }\end{array}$ & Similar to: Polyphenol oxidase B & 3.22 & 0.0119 & 19 & 3.43 & 0.0431 & 27 & 1.49 & 0.3526 & 25 \\
\hline M1BFJ1 & Patatin-01 & 1.84 & 1.0000 & 5 & 6.82 & 0.0610 & 7 & 9.56 & 0.1048 & 7 \\
\hline $\begin{array}{l}\text { M1AEP4 } \\
\text { M1BYS8 }\end{array}$ & $17-3 \mathrm{kDa}$ class II heat shock protein & 1.09 & 1.0000 & 61 & 3.61 & 0.0772 & 55 & 5.07 & 0.0038 & 55 \\
\hline M1AG22 & uncharacterized & 0.04 & 0.1700 & 45 & 0.08 & 0.0001 & 30 & 0.18 & 0.0096 & 27 \\
\hline $\begin{array}{l}\text { M1ACN9 } \\
\text { Q9AWA5 }\end{array}$ & $\begin{array}{l}\text { Similar to: alpha-glucan water dikinase; } \\
\text { alpha-glucan water dikinase }\end{array}$ & 0.81 & 1.0000 & 155 & 0.41 & 0.0001 & 105 & 0.42 & 0.0002 & 105 \\
\hline $\begin{array}{l}\text { P19595 } \\
\text { M1B150 }\end{array}$ & UTP-glucose-1-phosphate uridylytransferase & 0.37 & 0.0002 & 167 & 0.49 & 0.0001 & 120 & 0.53 & 0.0002 & 125 \\
\hline \multicolumn{11}{|l|}{ M1D2P7 } \\
\hline $\begin{array}{l}\text { Q00081 } \\
\text { P55242 }\end{array}$ & Glucose-1-phosphate adenyltransferase & 0.45 & 0.4430 & 55 & 0.34 & 0.0001 & 42 & 0.33 & 0.0038 & 32 \\
\hline \multicolumn{11}{|l|}{ M1BB30 } \\
\hline \multicolumn{11}{|l|}{ M1BB29 } \\
\hline \multicolumn{11}{|l|}{ M1AI49 } \\
\hline \multicolumn{11}{|l|}{ M0ZJC9 } \\
\hline \multicolumn{11}{|l|}{ M0ZJD0 } \\
\hline $\begin{array}{l}\text { M1AVV0 } \\
\text { Q00775 }\end{array}$ & Starch synthase Granule-bound starch synthase 1 & 0.69 & 0.8188 & 63 & 0.35 & 0.0001 & 59 & 0.39 & 0.0002 & 60 \\
\hline $\begin{array}{l}\text { P30924 } \\
\text { M1AM71 }\end{array}$ & 1,4-alpha-glucan-branching enzyme, & 0.71 & 0.8768 & 175 & 0.49 & 0.0017 & 130 & 0.63 & 0.8308 & 137 \\
\hline $\begin{array}{l}\text { M1AM70 } \\
\text { M1AM68 } \\
\text { M1AM69 }\end{array}$ & $\begin{array}{l}\text { Uncharacterized protein, similar to: } \\
\text { 1,4-alpha-glucan-branching enzyme, } \\
\text { Uncharacterized protein }\end{array}$ & & & & & & & & & \\
\hline $\begin{array}{l}\text { P55312 } \\
\text { M1CVH4 }\end{array}$ & Catalase isozyme 2 ; isozym 1 & 0.45 & 0.0002 & 95 & 0.35 & 0.0020 & 84 & 0.45 & 0.0829 & 85 \\
\hline M0ZMN7 & & & & & & & & & & \\
\hline P49284 & & & & & & & & & & \\
\hline
\end{tabular}


Table 3 (continued)

\begin{tabular}{|c|c|c|c|c|c|c|c|c|c|c|}
\hline \multirow{2}{*}{$\begin{array}{l}\text { Protein } \\
\text { Accession }^{\mathrm{a}}\end{array}$} & \multirow{2}{*}{$\begin{array}{l}\text { Description } \\
\text { Protein }\end{array}$} & \multicolumn{3}{|c|}{ Control not wounded } & \multicolumn{3}{|c|}{ Wounded + D. solani } & \multicolumn{3}{|c|}{ Wounded + Water } \\
\hline & & $\begin{array}{l}\text { Fold } \\
\text { change }^{b}\end{array}$ & $q^{\mathrm{c}}$ & $\#^{\mathrm{d}}$ & $\begin{array}{l}\text { Fold } \\
\text { change }\end{array}$ & $q$ & \# & $\begin{array}{l}\text { Fold } \\
\text { change }\end{array}$ & $q$ & \# \\
\hline $\begin{array}{l}\text { М1BT30 } \\
\text { P37830 }\end{array}$ & Glucose-6-phosphate 1-dehydrogenase & 1.03 & 1.0000 & 47 & 0.45 & 0.0774 & 32 & 0.49 & 0.4064 & 33 \\
\hline P32811 & Alpha-glucan phosphorylase, $\mathrm{H}$ isozyme & 0.29 & 0.0615 & 49 & 0.16 & 0.0882 & 46 & 0.20 & 0.0829 & 43 \\
\hline $\begin{array}{l}\text { M1D7J7 } \\
\text { M0ZHN3 }\end{array}$ & Malic enzyme & 0.58 & 0.9943 & 73 & 0.32 & 0.0999 & 53 & 0.41 & 0.0944 & 57 \\
\hline M1CIA9 & & & & & & & & & & \\
\hline $\begin{array}{l}\text { M1ACN9 } \\
\text { Q9AWA5 }\end{array}$ & $\begin{array}{l}\text { Similar to: alpha-glucan water dikinase; } \\
\text { alpha-glucan water dikinase }\end{array}$ & 0.81 & 1.0000 & 155 & 0.41 & 0.0001 & 105 & 0.42 & 0.0001 & 105 \\
\hline
\end{tabular}

${ }^{\mathrm{a}}$ UniProt identifier; ${ }^{\mathrm{b}}$ increase in protein abundance in the resistant DG 00-270 compared to the susceptible DG 08-305, significant changes in bold; ${ }^{\mathrm{c}} q$-value as reported by Diffprot; ${ }^{\mathrm{d}}$ number of peptides used in the comparison

tubers by Phytophthora infestans induces the accumulation of chymotrypsin inhibitors, which significantly inhibit mycelial growth of this pathogen. Senser et al. (1974) demonstrated the inhibitory effects of PIs from potato tubers on the diversity of proteolytic microorganisms isolated from rotten potato tubers. Significant changes in protein abundance were also observed when comparing potato cultivars that were resistant or susceptible to bacteria after mock inoculation. Regardless of inoculation treatment (inoculation with bacteria and mock-inoculation), the five potato cultivars had different protein pattern when analyzed by principal component analysis. The effect of treatments was smaller than the effect of potato cultivars, which could be separated along with level of resistance based on PC2. These results indicated that in the resistance tests, protein expression is partially associated with the response of tuber tissue to mechanical wounding. Ten proteins exhibited significantly increased levels in the resistant clone DG 00-270 compared to the susceptible clone DG 08-305, both after $D$. solani inoculation and mock inoculation (Table 3). Only two of these proteins, namely, PI2 and PT3K1, were selected in the tetraploid cultivars. The most prominent fold change between the diploid clones was observed for MCPI and MCPI-like proteins. These protein exhibited much higher fold changes following pathogenic invasion than after mock inoculation and in intact tubers. MCPIs are known to be wound-inducible inhibitors in plants (Molesini et al. 2018). In potato tubers, these proteins are among the most abundant PIs (Fischer et al. 2015). MCPI accumulation in wounded leaves of potato plants has been reported (Graham and Ryan 1981). In transgenic rice, a potato carboxypeptidase inhibitor gene was shown to provide resistance against the economically important pathogens Magnaporthe oryzae and Fusarium verticillioides (Quilis et al. 2007). The higher abundance of MCPIs in DG 00-270 than in DG 08-305 indicates the defensive role of these proteins in the response to bacterial inoculation. Notably, in our study, changes in MCPI abundance between the potato cultivars were not statistically significant. This result suggests that different mechanisms of resistance to $D$. solani are present in the cultivated and diploid potato plants.

Protein abundances reflect a dynamic balance among post-transcriptional, translational and protein modification/destruction processes (Vogel and Marcotte 2012). Complementary approaches, such as quantitative genomics, allow the identification of genetic factors involved in the defensive response of potato to D. solani, which is the aim of our future studies.

Acknowledgments The equipment used in the Mass Spectrometry Laboratory was sponsored in part by the Centre for Preclinical Research and Technology (CePT), a project cosponsored by the European Regional Development Fund and Innovative Economy, the National Cohesion Strategy of Poland.

Author's contributions RL conceived and coordinated the project, performed the experiments, performed part of the statistical analysis, and cowrote the manuscript; ZM performed protein extraction; KS performed protein extraction; MK performed data analysis; JD performed data analysis and wrote sections of the manuscript; and WM conceived the project and cowrote the manuscript. All authors contributed to manuscript revision, read and approved the submitted version. 
Funding This research was financially supported by a grant from the Ministry of Agriculture and Rural Development, Poland (grant/award number: 56 [BH-4-3-00-3-01; 2016-2018]).

\section{Compliance with ethical standards}

Conflict of interest The authors declare that the research was conducted in the absence of any commercial or financial relationship that could be construed as a potential conflict of interest.

Open Access This article is distributed under the terms of the Creative Commons Attribution 4.0 International License (http:// creativecommons.org/licenses/by/4.0/), which permits unrestricted use, distribution, and reproduction in any medium, provided you give appropriate credit to the original author(s) and the source, provide a link to the Creative Commons license, and indicate if changes were made.

\section{References}

Bakun M, Niemczyk M, Domanski D, Jazwiec R, Perzanowska A, Niemczyk S, Kistowski M, Fabijanska A, Borowiec A, Paczek L, Dadlez M (2012) Urine proteome of autosomal dominant polycystic kidney disease patients. Clin Proteomics 9(1):13. https://doi.org/10.1186/1559-0275-9-13

Barta J, Bartova V (2008) Patatin, the major protein of potato (Solanum tuberosum L.) tubers, and its occurrence as genotype effect: processing versus table potatoes. Czech J Food Sci 26:347-359

Barzic MR, Com E (2012) Proteins involved in the interaction of potato tubers with Pectobacterium atrosepticum: a proteomic approach to understanding partial resistance. J Phytopathol 160:561-575

Chung YS, Kim C, Jansky S (2017) New source of bacterial soft rot resistance in wild potato (Solanum chacoense) tubers. Genet Resour Crop Evol 64:1963-1969

Czajkowski R, Grabe GJ, Van der Wolf JM (2009) Distribution of Dickeya spp. and Pectobacterium carotovorum subsp. carotovorum in naturally infected seed potatoes. Eur J Plant Pathol 125:263-275

Davidsson PR, Kariola T, Niemi O, Palva ET (2013) Pathogenicity of and plant immunity to soft rot pectobacteria. Front Plant Sci 4(191). https://doi.org/10.3389/fpls.2013.00191

Elphinstone JG, Perombelon MCM (1986) Contamination of potatoes by Erwinia carotovora during grading. Plant Pathol 35:25-33

Fang X, Chen J, Dai L, Ma H, Zhang H, Yang J, Wang F, Chengqi Y (2015) Proteomic dissection of plant responses to various pathogens. J Proteome 15:1525-1543

Fischer M, Kuckenberg M, Kastilan R, Muth J, Gebhardt C (2015) Novel in vitro inhibitory functions of potato tuber proteinaceous inhibitors. Mol Genet Genomics 290:387-398

Golanowska M, Galardini M, Bazzicalupo M, Hugouvieux-CottePattat N, Mengoni A, Potrykus M, Slawiak M, Lojkowska E (2015) Draft genome sequence of a highly virulent strain of the plant pathogen Dickeya solani, IFB0099. Genome Announc 3. https://doi.org/10.1128/genomeA.00109-15

Graham JS, Ryan CA (1981) Accumulation of a metallocarboxypeptidase inhibitor in leaves of wounded potato plants. Biochem Biophys Res Commun 101:1164-1170

Kazemi-Pour N, Condemine G, Hugouvieux-Cotte-Pattat N (2004) The secretome of the plant pathogenic bacterium Erwinia chrysanthemi. Proteomics 4:3177-3186

Lapierre C, Pollet B, Negrel J (1996) The phenolic domain of potato suberin: structural comparison with lignins. Phytochemistry 42:949-953

Lebecka R, Flis B, Murawska Z (2018) Comparison of temperature effects on the in vitro growth and disease development in potato tubers inoculated with bacteria Pectobacterium atrosepticum, P. carotovorum subsp. carotovorum and Dickeya solani. J Phytopathol 166:654-662

Malinowska A, Kistowski M, Bakun M, Rubel T, Tkaczyk M, Mierzejewska J, Dadlez M (2012) Diffprot - software for non-parametric statistical analysis of differential proteomics data. J Proteome 75(13):4062-4073. https://doi.org/10.1016 /j.jprot.2012.05.030

Mattinen L, Nissinen R, Riipi T, Kalkkinen N, Pirhonen M (2007) Host-extract induced changes in the secretome of the plant pathogenic bacterium Pectobacterium atrosepticum. Proteomics 7:3527-3537

Molesini B, Rotino GL, Dusi V, Chignola R, Sala T, Mennella G, Pandolfini T (2018) Two metallocarboxypeptidase inhibitors are implicated in tomato fruit development and regulated by the inner no outer transcription factor. Plant Sci 266:19-26

Murawska Z, Dębski J, Szajko K, Lebecka R (2017) Isolation of proteins from potato tubers. Plant Breed Seed Sci 75:23-27. https://doi.org/10.1515/plass-2017-0005

Pasco C, Bozec M, Ellissèche D, Andrivon D (2006) Resistance behaviour of potato cultivars and advanced breeding clones to tuber soft rot caused by Pectobacterium atrosepticum. Potato Res 49:91-98

Pedregosa F, Varoquaux G, Gramfort A, Michel V, Thirion B, Grisel O, Blondel M, Prettenhofer P, Weiss R, Dubourg V, Vanderplas J, Passos A, Cournapeau D, Brucher M, Perrot M, Duchesnay E (2011) Scikit-learn: machine learning in python. J Mach Learn Res 12:2825-2830

Pérombelon MCM (2002) Potato diseases caused by soft rot erwinias: an overview of pathogenesis. Plant Pathol 51:112

Pritchard L, Humphris S, Saddler GS, Parkinson NM, Bertrand V, Elphinstone JG, Toth IK (2013) Detection of phytopathogens of the genus Dickeya using a PCR primer prediction pipeline for draft bacterial genome sequences. Plant Pathol 62:587596

Py B, Bortoli-German I, Haiech J, Chippaux M, Barras F (1991) Cellulase EGZ of Erwinia chrysanthemi: structural organisation and importance of His 98 and Glu133 residues for catalysis. Protein Eng 4:325-333

Quilis J, Meynard D, Vila L, Avilés FX, Guiderdoni E, San Segundo B (2007) A potato carboxypeptidase inhibitor gene provides pathogen resistance in transgenic rice. Plant Biotechnol J 5:537-553

Rehman S, Aziz E, Akhtar W, Ilyas M, Mahmood T (2017) Structural and functional characteristics of plant proteinase inhibitor-II (PI-II) family. Biotechnol Lett 39:647-666 
Ryan CA (1990) Protease inhibitors in plants: genes for improving defenses against insects pathogens. Annu Rev Phytopathol 28:425-449

Senser F, Belitz HD, Kaiser KP, Santarius K (1974) Suggestion of a protective function of proteinase inhibitors in potatoes: inhibition of proteolytic activity of microorganisms isolated from spoiled potato tubers. Z Lebensm Unters-Forsch 155: 100-101

Sepulchre JA, Reverchon S, Nasser W (2007) Modeling the onset of virulence in a pectinolytic bacterium. J Theor Biol 244: 239-257

Shewry PR (2003) Tuber storage proteins. Ann Bot London 91: 755-769

Smith PK, Krohn RI, Hermanson GT, Mallia AK, Gartner FH, Provenzano MD, Fujimoto EK, Goeke NM, Olson BJ, Klenk DC (1985) Measurement of protein using bicinchoninic acid. Anal Biochem 150:76-85

StatSoft Inc. (2011) STATISTICA (data analysis software system), version 10. Available from: www.statsoft.com

Toth IK, Birch PLJ (2005) Rotting softly and stealthily. Curr Opin Plant Biol 8:424-429

Toth IK, Bell KS, Holeva MC, Birch PRJ (2003) Soft rot Erwiniae: from genes to genomes. Mol Plant Pathol 4:17-30

Toth IK, van der Wolf JM, Saddler G, Lojkowska E, Hélias V, Pirhonen M, Tsror L, Elphinstone JG (2011) Dickeya species: an emerging problem for potato production in Europe. Plant Pathol 60:385-399

Tzeng K, McGuire RG, Kelman A (1990) Resistance of tubers from different potato cultivars to soft rot caused by Erwinia carotovora subsp. atroseptica. Am J Potato Res 67:287-305

Valueva TA, Revina TA, Kladnitskaya GV, Mosolov VV (1998) Kunitz-type proteinase inhibitors from intact and Phytophthora-infected potato tuber. FEBS Lett 426:131-134
Van der Hoorn RAL (2008) Plant proteases: from phenotypes to molecular mechanisms. Annu Rev Plant Biol 59:191-223

Van der Wolf JM, Nijhuis EH, Kowalewska MJ, Saddler GS, Parkinson N, Elphinstone JG, Pritchard L, Toth IK, Lojkowska E, Potrykus M, Waleron M, de Vos P, Cleenwerck I, Pirhonen M, Garlant L, Hélias V, Pothier JF, Pflüger V, Duffy B, Tsror L, Manulis S (2014) Dickeya solani sp. nov., a pectinolytic plant-pathogenic bacterium isolated from potato (Solanum tuberosum). Int J Syst Evol Microbiol 64:768-774

Vogel C, Marcotte EM (2012) Insights into the regulation of protein abundance from proteomic and transcriptomic analyses. Nat Rev Genet 13:227-232

Wickham H (2017) ggplot2 - elegant graphics for data analysis (2nd edition). J Stat Softw 77:1-3

Zhang X, Fu J, Hiromasa Y, Pan H, Bai G (2013) Differentially expressed proteins associated with Fusarium head blight resistance in wheat. PLoS One 8:e82079. https://doi. org/10.1371/journal.pone.0082079

Zimnoch-Guzowska E, Marczewski W, Lebecka R, Flis B, Schaefer-Pregl R, Gebhardt C (2000) QTL analysis of new sources of resistance to Erwinia carotovora ssp. atroseptica in potato done by ALFP, RFLP, and resistance-gene-like markers. Crop Sci 40:1156-1167

Publisher's note Springer Nature remains neutral with regard to jurisdictional claims in published maps and institutional affiliations. 